\title{
Economic and statistical research of development of rural areas in Samara region
}

\author{
O. F. Pyatova ${ }^{1}, T . V$. Shumilina $^{1, *}, M . N$. Kupryaeva ${ }^{2}, O$. V. Alekseeva ${ }^{3}$, and L. Dvorskiy ${ }^{4}$ \\ ${ }^{1}$ Department of Accounting and Statistics, Samara State Agrarian University, 446442 Kinel, Samara region, Russia \\ ${ }^{2}$ Department of Management and Marketing, Samara State Agrarian University, 446442 Kinel, Samara region, Russia \\ ${ }^{3}$ LLC Kutuluk, 43 Yubileynaya str., Bogatoe village, Bogatovskiy district, 446630 Samara region, Russia \\ ${ }^{4}$ Czech Breeding Services s.r.o. (Czech Republic), Komenskeho 221, 78373 Grygov Czech Republic
}

\begin{abstract}
Rural development is often analyzed in isolation from agricultural production. The article analyzes the dynamics of dairy cattle breeding indicators in Samara region. The purpose is to link the development of dairy farming with the development of rural areas.
\end{abstract}

\section{Introduction}

Currently, the development of rural areas which are one of the important elements of the national economy is uneven. Despite the dynamic growth of the agroindustrial industry of Samara region, the living standards of the rural population are behind the living standards in cities. Many social services are not available; there is an information and innovation gap between the city and the village which increases the outflow of the population [1].

In Samara region, there are rural settlements where there are no agricultural enterprises and other organizations. The population of these villages are forced to work in other settlements, or engage in the individual production of agricultural products. People do not have regular sources of income. Individual land plots are not profitable because of the underdeveloped cooperation, sales markets, and poor state regulation of the production of environmentally friendly, organic products.

The most acute problem is the lack of jobs for the younger generation and older people [2].

For the able-bodied category of rural residents, the most painful problem is the fear of losing their jobs. This is understandable, since in rural areas, employment opportunities are very limited, and the duration of the unemployment period exceeds the socially acceptable level [3].

In order to improve the living standards in the countryside, to overcome the shortage of specialists and skilled agricultural workers, the regional program "Sustainable Development of Rural Territories of Samara Region for 2014-2017 and until 2021" [4] was developed.

Agriculture and one of its directions - dairy cattle breeding play an important role in fulfilling the program tasks. Dairy cattle breeding is of great importance not only in ensuring food security of the country, but also in the social aspect. Its development contributes to the economic security and implementation of the labor potential of rural residents. It is one of the key sectors of large and small businesses in rural areas. This direction is crucial for the federal, municipal and regional authorities

From the foregoing, it follows that in order to preserve villages and a decent life for rural residents, it is necessary to consider the issue of increasing milk production as a priority task of national importance.

In order to assess the possibility of realizing the tasks set for the dairy industry, it is necessary to analyze in detail the current state of the dairy industry and assess the prospects. For the accelerated development of animal husbandry, there must be certain prerequisites. Necessary resources and favorable conditions are needed. The main ones are land, finances, personnel, animals, technologies and climatic conditions.

In the Samara region, there are advanced farms that use modern intensive animal husbandry technologies. Their experience should become a practical tool in planning new projects, including the projects in training specialists for animal husbandry.

\section{Materials and methods}

The information base for the study is data published on the official websites of the Federal State Statistics Service of the Russian Federation and Samara Region, the Ministry of Agriculture and Food of Samara Region.

The comparison method, methods of economic and statistical analysis (typological groupings, dynamics analysis, tabular and graphical methods of data presentation) were used. These methods made it possible to identify and analyze the efficiency of the development of dairy cattle breeding in Samara region.

\footnotetext{
* Corresponding author: tanyashum86@ mail.ru
} 


\section{Results and discussion}

In 2017, In Russia, Samara Region ranked $27^{\text {th }}$ by the milk production indicator (it ranked $30^{\text {th }}$ in 2013). IN the Volga Federal District, it ranked $9^{\text {th }}\left(11^{\text {th }}\right.$ in 2013) [5].

The main indicators of the development of dairy cattle breeding in Samara region for 2013-2017 are presented in Table 1.
The growth rate of the dairy herd for 2013-2017 amounted to $1.5 \%$. The peak was in 2016 , when the region had the maximum number of cows. Then there was a decrease in the number of cows. At the same time, the gross milk yield increased by $7.8 \%$. An increase in milk production is due to an increase in productivity of cows at a growth rate of $31.2 \%$.

Table 1. Indicators of dairy farming in Samara region

\begin{tabular}{|c|c|c|c|c|c|c|}
\hline Indicator & 2013 & 2014 & 2015 & 2016 & 2017 & Growth dynamics, \% \\
\hline $\begin{array}{c}\text { In all farms: } \\
\text { - the average annual number of cows, thou- } \\
\text { sand heads. }\end{array}$ & & & & & & \\
& 107.0 & 109.9 & 111.6 & 110.7 & 108.6 & 101.5 \\
\hline Growth rate (chain), \% & 100.0 & 102.7 & 101.5 & 99.2 & 98.1 & $\mathrm{x}$ \\
\hline - gross milk yield, thousand tons & 421.4 & 434.9 & 440.6 & 447.5 & 454.2 & 107.8 \\
\hline Growth rate (chain), \% & 100.0 & 103.2 & 101.3 & 101.6 & 101.5 & $\mathrm{x}$ \\
\hline - average annual productivity of cows, kg & 3938 & 3957 & 3948 & 4042 & 4182 & 106.2 \\
\hline Growth rate (chain), \% & 100.0 & 100.5 & 99.8 & 102.4 & 103.5 & $\mathrm{x}$ \\
\hline $\begin{array}{c}\text { The average annual productivity of cows in } \\
\text { agricultural organizations, kg }\end{array}$ & 4326 & 4659 & 4730 & 4729 & 4895 & 131.2 \\
\hline Growth rate (chain), \% & 100.0 & 107.7 & 101.5 & 100.0 & 103.5 & $\mathrm{x}$ \\
\hline
\end{tabular}

Source: [5]

In 2013, Samara Region ranked $7^{\text {th }}$ in the Volga Federal District [6] by the milk yield per cow; in 2017, it ranked $10^{\text {th }}$.

Despite a decrease in milk production by 5.7 percentage points from $55.4 \%$ in 2013 to $49.7 \%$ in 2017 , house- holds remain key milk producers. The share of peasant (farmer) households increased by $6.6 \%$ and amounted to $17.7 \%$ in 2017. Agricultural organizations produce 32.2$33.5 \%$ (Fig. 1).

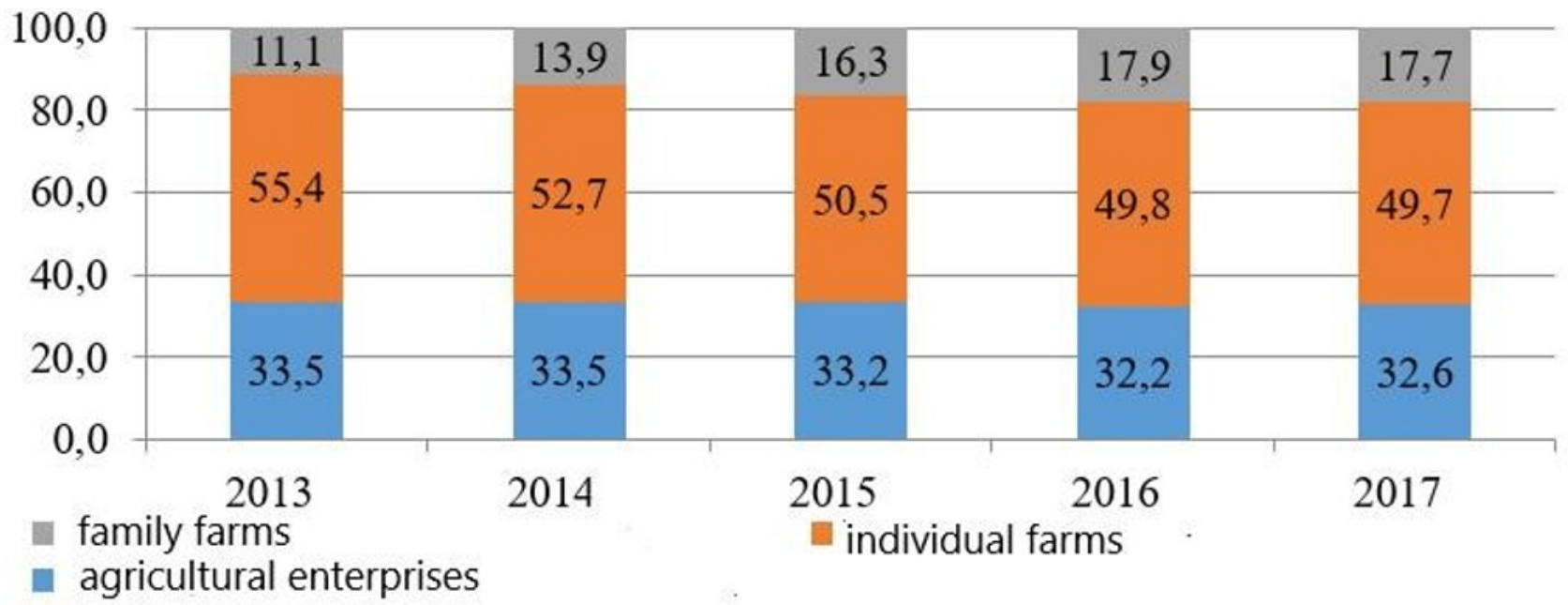

Fig 1. The structure of milk production by categories of farms in Samara region in 2013-2017, \%

The largest share of milk producers are agricultural enterprises located in the central natural and economic zone of the Samara region.

These are state unitary enterprise of the Samara region "Kupinskoe," OOO "Radna," OOO agricultiral enterprise "EcoProduct," AO "Niva," agricultural production cooperative (collective farm) named after Kujbyshev, OOO "Klondaik," AO "Plemzavod Kriazh," and other, which contributed to the growth of gross milk yield by $9.6 \%$.

The greatest increase was observed in agricultural organizations of the southern zone of Samara region (table 2). The growth rate was $23.9 \%$. One of the large farms located in this zone is OOO agricultural production cooperative Olginsky. 
Table 2. Milk production in the zones of the Samara region, tons

\begin{tabular}{|c|c|c|c|c|c|c|}
\hline Enterprise type & 2013 & 2014 & 2015 & 2016 & 2017 & Growth rate, $\%$ \\
\hline \multicolumn{7}{|c|}{ North zone } \\
\hline Agricultural enterprises & 52021 & 50698 & 47874.17 & 47062.83 & 48447.9 & 93.1 \\
\hline Individual farms & 66363 & 63198 & 60583.39 & 62441.07 & 62896.84 & 94.8 \\
\hline Family farms & 14634 & 17431 & 16148.57 & 20818.16 & 21563.57 & 147.4 \\
\hline Total & 133018 & 131327 & 124606.1 & 130322.1 & 132908.3 & 99.9 \\
\hline \multicolumn{7}{|c|}{ Central zone } \\
\hline Agricultural enterprises & 74400 & 76227 & 80485.44 & 79041.52 & 81556.9 & 109.6 \\
\hline Individual farms & 78415 & 76867 & 73239.04 & 73134.94 & 72910.15 & 93.0 \\
\hline Family farms & 16607 & 25617 & 35947.43 & 38093.53 & 38233.93 & 230.2 \\
\hline Total & 169422 & 178711 & 189671.9 & 190270 & 192701 & 113.7 \\
\hline \multicolumn{7}{|c|}{ South zone } \\
\hline Agricultural enterprises & 14526 & 18578 & 17887.3 & 18190.7 & 18004.7 & 123.9 \\
\hline Individual farms & 76365 & 77725 & 77266.93 & 76283.44 & 78676.86 & 103.0 \\
\hline Family farms & 15632 & 17252 & 19698.86 & 21225.67 & 20765.37 & 132.8 \\
\hline Total & 106523 & 113555 & 114853.1 & 115699.8 & 117446.9 & 110.3 \\
\hline
\end{tabular}

In the agricultural organizations of the northern zone, milk production decreased by $6.9 \%$ due to a significant decrease in the number of cows.

In the households of the northern and central natural and economic zones, milk production is characterized by a negative trend: the reduction was $2 \%$ and $7.0 \%$, respectively. Over the same period, in the southern zone, household milk production increased by $3.0 \%$. The growth of milk yield in peasant farms is observed in all zones. Moreover, the largest growth (2.3 times) was observed in the central zone. The main factors influencing the change in production volumes are the number and productivity of cows.

In agricultural organizations, regardless of their location, the number of cows decreased by $9.3 \%$. In the households the number of cows decreased with the exception of southern farms where the number of cows increased only by $0.7 \%$.

In peasant farms, the number of cows increased. The largest increase was observed in the central zone (by 2.1 times). On average, the indicator increased by $69.4 \%$ and reached a value of 27.2 thousand heads. This accounts for $25.3 \%$ of the total number of cows in the region.

It should be noted that for 2013-2017, the migration inflow into the countryside of the central naturaleconomic zone amounted to over 5 thousand people.

One of the main reasons for reducing the number of dairy herds is management decisions of the owners of individual enterprises due to the low profitability of dairy farming. At the end of 2017, the profitability of dairy enterprises amounted to $9.4 \%$; without the government financial assistance, they would be unprofitable $(-2.5 \%)[7]$.

To reflect the dynamics of cow productivity in Samara region for 2013-2017, an economic-mathematical model of the third-order polynomial was constructed for each household category. The calculation results are presented in Figure 2. The following conventions are introduced in the equations obtained:

$\mathrm{y}$ - productivity of cows in the Samara region, $\mathrm{kg}$;

$\mathrm{x}$ are the numbers of time periods to which the levels of the time series belong.
The models are statistically reliable, the variation in agricultural enterprises reaches $99.92 \%$, in households $88.89 \%$, in peasant farms $-89.64 \%$, in farms of all categories (excluding cities) $-94.04 \%$.

The interpretation of the model parameters is as follows:

- productivity of cows grew in nominal terms, with an average acceleration: in agricultural organizations $19.571 \mathrm{~kg}$, in households - $5.0714 \mathrm{~kg}$, in peasant farms $24.571 \mathrm{~kg}$, in households of all categories (excluding cities) - $23.429 \mathrm{~kg}$;

- the average annual change in cow productivity: in agricultural organizations - $24.571 \mathrm{~kg}$, in households $14.329 \mathrm{~kg}$, in peasant farms $-134.43 \mathrm{~kg}$, in farms of all categories (excluding cities) - $113.17 \mathrm{~kg}$.

Thus, agricultural organizations make the largest contribution to the development of dairy cattle breeding and rural areas.

Currently, the Government is implementing measures to small businesses and all forms of self-employment in the rural areas $[8,9]$. In Samara region, within the program "Development of Agriculture and Regulation of Agricultural Product Markets of Samara Region for 2014-2020", the program "Development of Small Businesses" has been implemented for 7 years.

Since 2012, one of the most demanded support forms has been grants provided to novice farmers and grants provided for the development of family livestock farms on the basis of peasant farms.

In 2012-2016, grants in the amount of 1.5 million rubles were provided to novice farmers. These funds could be spent on the purchase of farm animals, agricultural machinery and trucks, production and processing equipment. One-time assistance in the amount of up to 250 thousand rubles was provided to the households.

One more priority of the agricultural policy is implementation of measures aimed at creating comfortable conditions in rural areas. Within the federal programs "Social development of rural areas" and "Sustainable development of rural areas", the Ministry of Agriculture and Food of Samara Region developed measures to provide citizens with houses and social infrastructure facilities [10]. 
The total funding for the activities of the state program "Sustainable Development of Rural Areas" in the Samara Region from 2014 to 2018 amounted to 3.78 billion rubles, including 1.4 billion rubles from the federal budget and more than 2 billion rubles at the expense of the regional budget.

The action of the state program is accompanied by a positive result [11]. During the implementation of the program, 1260 families received social payments for the construction and purchase of housing in rural areas. In 2014-2018, during the implementation of the state pro-

Agricultural enteprises

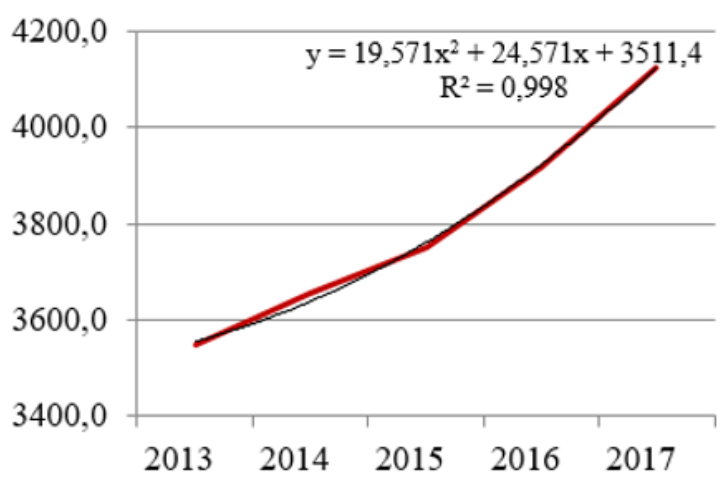

Family farms

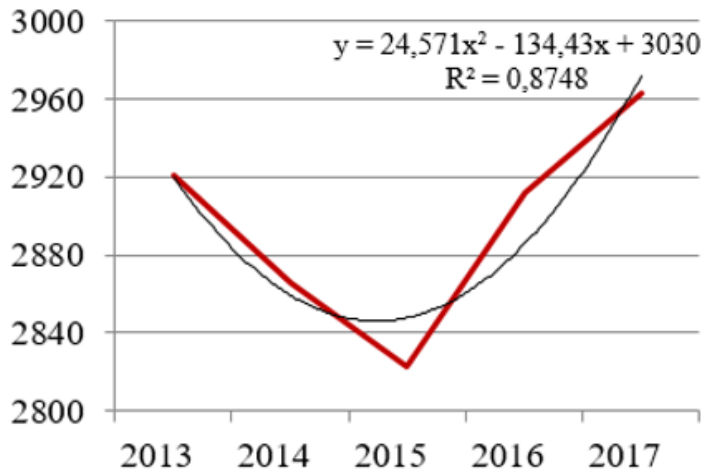

gram, 19 village first-aid stations, 28 universal sports grounds, more than $43 \mathrm{~km}$ of gas pipelines, more than 67 $\mathrm{km}$ of water pipelines were constructed [7].

At the end of May 2019, the state program "Integrated Development of Rural Areas" for the period 20202025 was approved, which provides for the provision of support for the improvement of rural areas and the preservation of the share of the rural population in the total population [12].

\section{Farms}

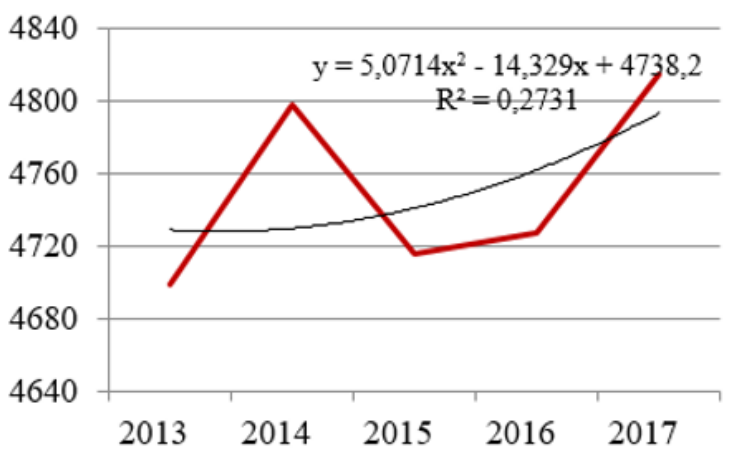

All categories of farms (excluding cities)

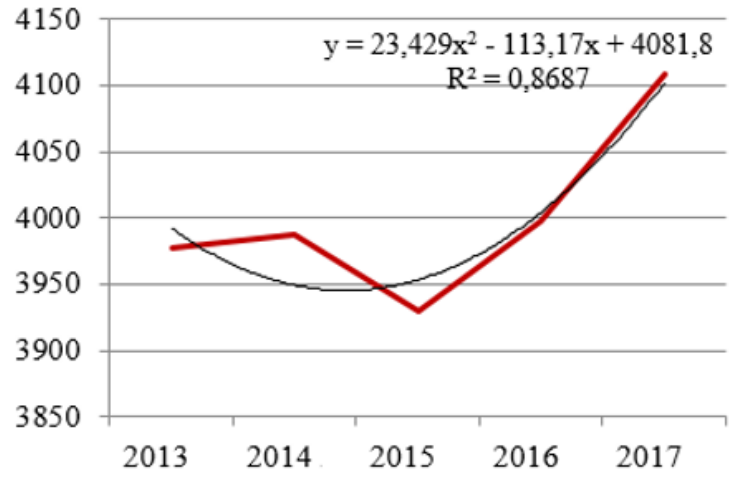

Fig. 2. Productivity of cows in Samara region, $\mathrm{kg}$

\section{Conclusion}

Due to the system of state support measures, agricultural producers achieved positive financial results which created prerequisites for the development of rural areas.

It is impossible to provide the regional consumer market with competitive agricultural products without sustainable rural development.

Dairy cattle breeding is a key sector in agriculture, which contributes to year-round employment of the rural population, ensures domestic consumption of crop products, and economic relationships.

These and other factors determine its paramount importance in the social development of rural territories. Economists argue that one dairy worker creates seven jobs in other sectors of the economy [7]. The gradual extinction of villages has acquired a steady tendency. One of the main reasons is the collapse of dairy farms, which gave work to the villagers and supported their households.

Therefore, the successful development of dairy farming in the Samara region will not only increase jobs, increase employment and improve the migration mood of rural residents, but also contribute to the development of social and engineering infrastructure of rural areas of the region.

\section{References}

1. Sustainable Rural Development Strategy Retrieved from: http://www.sgubern.ru/articles/4856/6859/

2. L.V. Bondarenko, Development of rural territories of Russia: Estimates, opinions, expectations Sociological research 3(January), 76-82 (2016)

3. L. V. Bondarenko, Urban and Rural Socioeconomic Disparities: Scientific Views and Domestic Practic- 
es Herald of the Russian Academy of Sciences 88(5), 320-329 (2018)

4. On the approval of the program of Samara region "Sustainable development of rural territories of Samara region for 2014-2017 and until 2021" (as amended on April 17, 2019) Retrieved from: http://docs.cntd.ru/document/464008926

5. Regions of Russia. Socio-economic indicators (Rosstat, Moscow, 2018) Retrieved from: http://www.gks.ru/

6. R.V. Nekrasov, Development of the dairy cluster of the Samara region in 2009-2013: results, problems, prospects Economics of agricultural and processing enterprises 6, 30-36 (2015)

7. Ministry of Agriculture and Food of Samara region. Official site Retrieved from: http://mcx.samregion.ru/

8. A.N. Gerasimov, Ye.I. Gromov, A.V. Nesterenko, T.Y. Bezdolnaya, J.E. Klishina, Government control of regional agricultural economic systems under institutional transformations Mediterranean J. of Social Sciences 6(5), 200-208 (2015)
9. E.G. Kovalenko, O. Y. Yakimova, E. V. Avtaykina, O. O. Zaytseva, Problems and Mechanisms of Sustainable Development of Rural Areas (at the example of the Republic of Mordovia) European Research Studies J. XIX, (3), Part A (2016) Retrieved from: http://www.ersj.eu/index.php?option=com_content $\&$ task=view\&id $=666$.

10. R.V. Nekrasov, Agrarian policy of the Samara region in the conditions of import substitution Intellect. Innovation Investments 2, 4-14 (2018)

11. N.N. Muhametova, The basics of development of rural areas: investments, strategy, experience Russian entrepreneurship 17(21), 2885-2894 (2016) doi: 10.18334/rp.17.21.37078

12. On the approval of the state program of the Russian Federation "Integrated development of rural areas" and on making amendments in some acts by the Government of the Russian Federation. Russian Federation governmental order from 31 May 2019 No. 696 Retrieved from: http://government.ru/docs/36905/ 